\title{
Biotechnological Medicines in the Russian Pharmaceutical Market: New Pharmacopeia Requirements and the Status of Restrictive Lists
}

\author{
Nana Bekhorashvili*, Elena Revovna Zakharochkina, Maria Grigorievna Rayisyan, Rimma Yuiryevna Garankina
}

Department of Regulatory Relations on the Circulation of Pharmaceuticals and Medical Products, Sechenov First Moscow State Medical University, Moscow, Russia

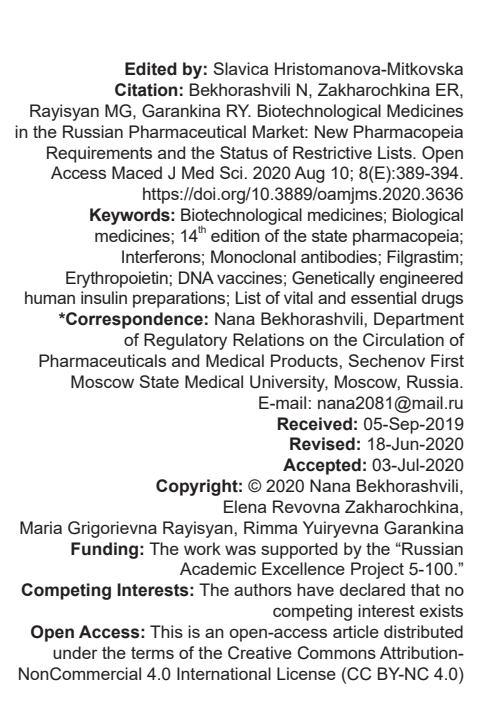

\section{Introduction}

Biotechnological medicines refer to biological medicines and occupy the most important place in modern healthcare.

Since 2014, the national state regulation of various aspects related to the circulation of the medicines in this group has been actively improved [1], [2], [3], [4], [5], [6].

The development of a common market for medicines within the framework of the Eurasian Economic Union is accompanied by the harmonization of interstate regulatory requirements, including the circulation of biological products [7], [8], [9], [10].

At the end of 2018, Russia approved the $14^{\text {th }}$ edition of the State Pharmacopeia, which implements many new requirements for biotechnological preparations.

The annually approved list of vital and essential drugs and other restrictive lists provide priority health needs for the prevention and treatment of diseases. For subjects of the pharmaceutical market, information on updating the data of the lists, in which biological medicines occupy a prominent place, is always relevant and interesting.

\section{Methods}

Content analysis of the national Federal law on the circulation of medicines by the keywords "biotechnological medicines", "biological medicines" and identification of regulatory frameworks for this group of medicines have been conducted.

System analysis of the new $14^{\text {th }}$ edition of the State Pharmacopeia to establish general pharmacopeia monographs (hereinafter - GPM) and the monographs on biotechnological medicines, and determine novelty (Federal Electronic Medical Library femb.ru sfemb/ pharmacopea.php). 
Analysis of the newly introduced general pharmacopoeia monograph "Biotechnological medicines" and identification of the basic requirements for producers for the quality of the medicines in this group were made.

Analysis of the main groups of biotechnological medicines in the $14^{\text {th }}$ edition of the State Pharmacopeia revealing the peculiarities of pharmacopeia regulation under the new general pharmacopeia monographs.

Up-to-date content analysis of the restrictive lists for 2019, identification of vital and essential drugs, the list of preferential provision drugs, and the medicines for twelve high-cost nosologies by groups of biotechnological medicines in new general pharmacopeia monographs.

Studying the results of the evaluation of the inclusion of medicines in the restrictive lists for 2020 on the official website of the Ministry of Health of Russia and determining the prospects for new biotechnological medicines.

\section{Results}

In the national legislation, the concept of "Biotechnological medicines" first appeared in 2015. Biotechnological medicines belong to one of four groups of biological medicines.

In general, biological medicines are the drugs whose active substance is produced or isolated from a biological source, with a combination of biological and physicochemical methods being necessary for determining their properties and quality.

The federal law on the circulation of medicines defines biotechnological medicines as the drugs produced using biotechnological processes and methods (including DNA recombinant technology, technology for the controlled expression of genes encoding biologically active proteins in prokaryotes and eukaryotes, including altered mammalian cells), hybridoma technology, and monoclonal antibodies method.

The order of the Ministry of Health of Russia No. 749 dated October 31, 2018, approved the general pharmacopeia monographs and the pharmacopeia monographs, and also established that they constituted the $14^{\text {th }}$ edition of the new State Pharmacopeia.

The $14^{\text {th }}$ edition of the State Pharmacopeia has introduced the general pharmacopeia monograph "Biotechnological medicines" (hereinafter referred to as the GPM.1.7.1.0011.18 "Biotechnological medicines"), as well as other general pharmacopeia monographs for certain groups of biotechnological preparations (hereinafter the BtM).

The BtM may contain proteins, peptides or derivatives of proteins and peptides, glycoproteins, live or inactivated microbes (bacteria, viruses), their antigens, antibodies to them, metabolites, and other biologically-sourced active substances (e.g., probiotics, bacteriophages, cytokines, monoclonal antibodies, recombinant proteins, etc.).

The BtM may include excipients of various purposes (stabilizers, sorbents, preservatives, fillers, etc.).

It is important to note that the general pharmacopeia monograph of the $14^{\text {th }}$ edition of the State Pharmacopeia "Biotechnological Medicines" does not apply to antibiotics, synthetic peptides and polypeptides, heparins, vitamins, and cell metabolites.

The safety of BtM is based on strict control of their starting materials. When assessing the risks of contamination of feedstock and starting materials, special attention is paid to the risk related to contamination with spongiform encephalopathy of animals (GPM "Risk of transmission of spongiform encephalopathy of animals") and latent viruses (GPM "Viral safety"). Attention should also be paid to starting materials in direct contact with process equipment or products (such as nutrient media used to simulate aseptic filling and lubricants that may come into contact with the product).

The biologically-sourced cells and materials used in the production must be characterized by and meet the requirements of microbiological and viral safety under the general pharmacopeia monograph "Requirements for cell cultures-substrates for the production of biological medicines."

To prevent unwanted changes in properties as a result of repeated subcultures or a large number of generations, the production of biological pharmaceutical substances and medicines obtained from microorganism cultures, cell cultures or propagation in embryos, tissues, and organs of animals should be based on the main and working seed culture system and (or) cell banks. Such a system may not apply to all types of high-tech medicines (Table 1).

Table 1: Main conditions for ensuring quality in the production of the BtM

\footnotetext{
The use in the production of only studied, genetically stable production strains of microbes and strains-producers characterized and deposited in the official collections that have been annually monitored for all biological properties as per the specified requirements

At the same time, based on the materials on the study of the genetic stability of the production strain, the number of passages of the microbe is limited (GPM "Probiotics, GPM "Bacteriophages," GPM "Medicines obtained by recombinant DNA methods") The use of adequate culture media with high growth properties (raw materials, reactants, and reagents used in the production of culture media must have quality certificates) The use of cell culture, under the WHO recommendations, deposited in the official collections and approved for use in production (when culturing cells, the use of native human blood serum and penicillin group antibiotics is not allowed) (GPM "Requirements for cell cultures-substrates for the production of biological medicines")

Validation of all stages of the production process. Tests as part of the validation of the technological process should include a proper assessment of both the technological process of production and each of its stages separately (e.g., the cell cultivation stage, the stage of collecting cells grown in culture, the stages of cleaning, mixing, sterilization, filling, etc.)

filling, etc.) biological methods, which are characterized by a higher degree of variability

The methods used for testing should be described as detailed as possible with the qualification of reactants, reagents, laboratory equipment, instruments, requirements for animals, strains of microbes and cell cultures, etc.
} 
In the $14^{\text {th }}$ edition of the State Pharmacopeia, fifteen general pharmacopeia monographs, eight of which had been introduced for the $1^{\text {st }}$ time, were devoted to biotechnological medicinal products as objects (Table 2).

Table 2: BtM in the $14^{\text {th }}$ edition of the State Pharmacopeia

\begin{tabular}{|c|c|c|}
\hline $\begin{array}{l}\text { Serial number as per the } \\
14^{\text {th }} \text { edition of the SP }\end{array}$ & $\begin{array}{l}\text { General pharmacopeia } \\
\text { monograph }\end{array}$ & $\begin{array}{l}\text { List changes as per the } \\
14^{\text {th }} \text { edition of the SP }\end{array}$ \\
\hline 242 & $\begin{array}{l}\text { Bacteriophages monograph GPM. } \\
1.7 .1 .0002 .15\end{array}$ & \\
\hline 243 & $\begin{array}{l}\text { Bifid-containing Probiotics } \\
\text { GPM.1.7.1.0003.15 }\end{array}$ & \\
\hline 245 & $\begin{array}{l}\text { Coli-containing Probiotics } \\
\text { GPM.1.7.1.0003.15 }\end{array}$ & \\
\hline 246 & $\begin{array}{l}\text { Lactic-containing Probiotics } \\
\text { GPM.1.7.1.0006.15 }\end{array}$ & \\
\hline 247 & $\begin{array}{l}\text { Recombinant DNA Medicines } \\
\text { GPM.1.7.1.0007.15 }\end{array}$ & \\
\hline $\begin{array}{l}248 \\
249\end{array}$ & $\begin{array}{l}\text { Probiotics GPM.1.7.1.0008.15 } \\
\text { Spore probiotics }\end{array}$ & \\
\hline 250 & $\begin{array}{l}\text { GPM.1.7L.0009.15 } \\
\text { Biological medicines } \\
\text { GPM.1.7.1.0010.18 }\end{array}$ & $\begin{array}{l}\text { Introduced for the } 1^{\text {st }} \\
\text { time }\end{array}$ \\
\hline 251 & $\begin{array}{l}\text { Biotechnological medicines } \\
\text { GPM.1.7.1.0011.18 }\end{array}$ & $\begin{array}{l}\text { Introduced for the } 1^{\text {st }} \\
\text { time }\end{array}$ \\
\hline 252 & Interferons GPM.1.7.1.0012.18 & $\begin{array}{l}\text { Introduced for the } 1^{\text {st }} \\
\text { time }\end{array}$ \\
\hline 253 & DNA vaccines GPM.1.7.1.0013.18 & $\begin{array}{l}\text { Introduced for the } 1^{\text {st }} \\
\text { time }\end{array}$ \\
\hline 254 & $\begin{array}{l}\text { Monoclonal antibodies for medical } \\
\text { use GPM.1.7.1.0014.18 }\end{array}$ & $\begin{array}{l}\text { Introduced for the } 1^{\text {st }} \\
\text { time }\end{array}$ \\
\hline 255 & Filgrastims GPM.1.7.1.0015.18 & $\begin{array}{l}\text { Introduced for the } 1^{\text {st }} \\
\text { time }\end{array}$ \\
\hline 256 & Erythropoietin GPM.1.7.1.0016.18 & $\begin{array}{l}\text { Introduced for the } 1^{\text {st }} \\
\text { time }\end{array}$ \\
\hline 257 & $\begin{array}{l}\text { Genetically engineered } \\
\text { human insulin preparations } \\
\text { GPM.1.7.1.0017.18 }\end{array}$ & $\begin{array}{l}\text { Introduced for the } 1^{\text {st }} \\
\text { time }\end{array}$ \\
\hline
\end{tabular}

biotechnological preparations in the $14^{\text {th }}$ edition of the

State Pharmacopeia have the following serial numbers:

Pirogenal: 593-594, interferons: 586, 615, bacteriophages: 609-612, 624-631, and probiotics: 603-608, 616-623.

The content analysis of the new general pharmacopeia monographs has made it possible to determine brief characteristics and identify regulatory features for specific groups of BtM.

The general pharmacopeia monograph "Interferons" (GPM “Interferons") applies to the interferons obtained through the recombinant DNA technology using bacterial or mammalian cells as an expression system.

Interferons belong to the group of cytokines and are globular proteins being the broad-spectrum multifunctional bioregulators.

The main biological properties of interferons are manifested in their antiviral, antiproliferative, and immunomodulatory effects.

Three types of interferons are distinguished by origin, as follows:

- IFN $\alpha$ - leukocyte (produced by leukocytes, plasmacytoid dendritic cells, and monocytes/ macrophages)

- $\quad$ IFN $\beta$ - fibroblast (produced by fibroblasts and epithelial cells)

- $\quad$ IFN $\gamma$-immune (produced by T-lymphocytes and natural killer cells).

By the production method, IFNs are divided into two groups: Natural (first-generation IFN) and recombinant ones obtained using genetically engineered technology (second-generation IFN).

Interferon preparations for parenteral administration are widely used in health-care practice for the treatment of many severe viral diseases, including viral hepatitis $B, C, D$, multiple sclerosis, and a wide range of oncological diseases.

Topical preparations (ointments, suppositories, drops, etc.) with some nosological forms are capable of ensuring the accumulation of large concentrations of the medication directly in the lesion in the absence of side effects characteristic of parenteral administration of high interferon doses. Due to the high concentration, in the focus of infection, a pronounced local antiviral and immunostimulating effect is achieved with a slight systemic absorption.

The quality indicators and requirements for them that depend on the medication form are regulated by the general pharmacopeia monographs on the relevant dosage form: GPM "Parenteral dosage forms," GPM "Aerosols and sprays," GPM "Opthalmic dosage forms," GPM "Ointments," etc.

It is important to note that the GPM "Interferons" does not apply to the modified (pegylated [obtained by attaching polyethylene glycol]) interferons.

The list of vital and essential drugs for 2019 includes interferons by groups L03A immunostimulants, L03AB interferons: Interferon-alpha, interferon beta-1a, interferon beta-1b, Interferon-gamma, peginterferon alpha-2a, peginterferon alfa-2b, peginterferon beta- $1 a$, and peginterferon alfa- $2 \mathrm{~b}$.

Interferon alfa, peginterferon alfa-2a, and peginterferon alfa- $2 b$ are included in the list of medicines prescribed by the decision of the medical commissions of medical organizations.

To provide medicines to the patients with multiple sclerosis that is one of the 12 high-cost nosologies, the relevant restrictive list provides for the purchase of the following medicines: Interferon-beta-1a, interferon beta-lb, and peginterferon beta- $1 \mathrm{a}$.

The general pharmacopeia monograph "Monoclonal Antibodies" defines that monoclonal antibodies for medical use are immunoglobulins or fragments of immunoglobulins characterized by strict antigenic specificity and produced by a single cell clone. Monoclonal antibodies can be conjugated to other substances, including radioactive labels.

Monoclonal antibodies are produced using recombinant DNA and hybridoma technology and can also be produced using other technologies.

Types of monoclonal antibodies are as follows:

Chimeric monoclonal antibodies, in which the variable domains of the heavy and light chains of a human immunoglobulin are replaced by the relevant immunoglobulin domains of a different species origin 
(mainly rodents - mice or rats) with the required antigenic specificity.

Humanized monoclonal antibodies, in which three short hypervariable sequences of the variable domains of each immunoglobulin chain (regions determining the complementary antigen-binding CDRs), are of murine (or other) origin and are integrated into the structure of the variable domains of a human immunoglobulin. Other changes in the hypervariable sequence may be introduced to improve antigen binding.

Recombinant human antibodies, in which the variable domains of the heavy and light chains of a human immunoglobulin are combined with a constant region of a human immunoglobulin.

The production of monoclonal antibodies is based on a system of cell banks (the Main Cell Bank and the Working Cell Bank) derived from cloned cells. The biologically-sourced cells and materials used in the manufacturing process should be characterized under the requirements outlined in the GPM "Requirements for cell cultures - substrates for the production of biological medicines," and the GPM "Medicines obtained by recombinant DNA methods."

The stages of the production process for monoclonal antibodies should be characterized as per the requirements outlined in the GPM "Medicines obtained by recombinant DNA methods." If different monoclonal antibodies are produced at the same production site, the authentication method must uniquely identify each monoclonal body produced in the presence of the others.

Monoclonal antibody medicines are available in the following parenteral dosage forms:

Injection and infusion forms (solution for injection, solution for infusion, and solution for subcutaneous administration)

- Concentrates for the injection and infusion forms (concentrate for the solution for infusion)

- $\quad$ Solid dosage forms intended for the injection and infusion dosage forms (lyophilizate for solution for infusion, etc.).

Lyophilizate can be supplied complete with a solvent approved for medical use, whereas the solvent should not affect the quality of the medicine.

It is important to note that the requirements of the GPM "Monoclonal Antibodies" do not apply to monoclonal antibodies that are used as reagents in the production of other medicines, monoclonal antibodies obtained in vivo (in the form of ascites), and monoclonal antibodies for in vitro diagnostic purposes.

The list of vital and essential drugs for 2019 includes 36 names of monoclonal antibody preparations, 19 of which are also included in the list of preferential provision drugs, which are prescribed by the decision of the medical commission (Table 3).
Table 3: Monoclonal antibodies in the list of vital and essential drugs for 2019

\begin{tabular}{|c|c|c|c|}
\hline C10AX & $\begin{array}{l}\text { Other lipid-lowering } \\
\text { medicines }\end{array}$ & $\begin{array}{l}\text { Alirocumab* } \\
\text { Evolocumab }\end{array}$ & $\begin{array}{l}\text { Solution for subcutaneous } \\
\text { administration } \\
\text { Solution for subcutaneous } \\
\text { administration }\end{array}$ \\
\hline \multirow[t]{2}{*}{ J06BB } & $\begin{array}{l}\text { Specific } \\
\text { immunoglobulins }\end{array}$ & & \\
\hline & & Palivizumab & $\begin{array}{l}\text { Lyophilizate for solution for } \\
\text { intramuscular administration }\end{array}$ \\
\hline \multirow[t]{4}{*}{ L01XC } & Monoclonal antibodies & $\begin{array}{l}\text { Atezolizumab } \\
\text { Bevacizumab* } \\
\text { Blinatumomab } \\
\text { (New 2019) } \\
\text { Brentuximab } \\
\text { vedotin } \\
\text { Daratumumab } \\
\text { Ipilimumab (New } \\
\text { 2019) }\end{array}$ & $\begin{array}{l}\text { Infusion solution concentrate } \\
\text { Infusion solution concentrate } \\
\text { Powder for the infusion solution } \\
\text { concentrate } \\
\text { Lyophilizate for the infusion } \\
\text { solution concentrate } \\
\text { Infusion solution concentrate } \\
\text { Infusion solution concentrate }\end{array}$ \\
\hline & & $\begin{array}{l}\text { Nivolumab } \\
\text { Obinutuzumab } \\
\text { Panitumumab* } \\
\text { Pembrolizumab } \\
\text { Pertuzumab* } \\
\text { Rituximab* }\end{array}$ & $\begin{array}{l}\text { Infusion solution concentrate } \\
\text { Infusion solution concentrate } \\
\text { Infusion solution concentrate } \\
\text { Infusion solution concentrate } \\
\text { Infusion solution concentrate } \\
\text { Infusion solution concentrate } \\
\text { solution for subcutaneous } \\
\text { administration }\end{array}$ \\
\hline & & Trastuzumab* & $\begin{array}{l}\text { Lyophilizate for the infusion } \\
\text { solution concentrate infusion } \\
\text { solution lyophilizate solution for } \\
\text { subcutaneous administration }\end{array}$ \\
\hline & & $\begin{array}{l}\text { Trastuzumab } \\
\text { emtansine } \\
\text { Cetuximab* }^{*}\end{array}$ & $\begin{array}{l}\text { Lyophilizate for the infusion } \\
\text { solution concentrate } \\
\text { Infusion solution }\end{array}$ \\
\hline \multirow[t]{5}{*}{ L04AA } & $\begin{array}{l}\text { Selective } \\
\text { immunosuppressants }\end{array}$ & & \\
\hline & & Alemtuzumab & Infusion solution concentrate \\
\hline & & $\begin{array}{l}\text { Belimumab } \\
\text { (New 2019) } \\
\text { Vedolizumab* }\end{array}$ & $\begin{array}{l}\text { Lyophilizate for the infusion } \\
\text { solution concentrate } \\
\text { Lyophilizate for the infusion } \\
\text { solution concentrate }\end{array}$ \\
\hline & & $\begin{array}{l}\text { Natalizumab } \\
\text { Ocrelizumab } \\
\text { (New 2019) }\end{array}$ & $\begin{array}{l}\text { Infusion solution concentrate } \\
\text { Infusion solution concentrate }\end{array}$ \\
\hline & & Eculizumab & Infusion solution concentrate \\
\hline \multirow[t]{4}{*}{ LO4AB } & $\begin{array}{l}\text { Tumor necrosis } \\
\text { factor inhibitors alpha }\end{array}$ & Adalimumab & $\begin{array}{l}\text { Solution for subcutaneous } \\
\text { administration }\end{array}$ \\
\hline & & Golimumab* & $\begin{array}{l}\text { Solution for subcutaneous } \\
\text { administration }\end{array}$ \\
\hline & & Infliximab* & $\begin{array}{l}\text { Infusion solution lyophilizate for } \\
\text { the infusion solution concentrate }\end{array}$ \\
\hline & & $\begin{array}{l}\text { Certolizumab } \\
\text { pégol }^{*}\end{array}$ & $\begin{array}{l}\text { Solution for subcutaneous } \\
\text { administration }\end{array}$ \\
\hline \multirow[t]{5}{*}{ L04AC } & Interleukin inhibitors & Basiliximab & $\begin{array}{l}\text { Lyophilizate for solution for } \\
\text { intravenous administration }\end{array}$ \\
\hline & & Canakinumab* & $\begin{array}{l}\text { Lyophilizate for solution for } \\
\text { subcutaneous administration }\end{array}$ \\
\hline & & Secukinumab* & $\begin{array}{l}\text { Lyophilizate for solution for } \\
\text { subcutaneous administration } \\
\text { solution for subcutaneous } \\
\text { administration }\end{array}$ \\
\hline & & Tocilizumab* & $\begin{array}{l}\text { Infusion solution concentrate } \\
\text { solution for subcutaneous } \\
\text { administration }\end{array}$ \\
\hline & & Ustekinumab* & $\begin{array}{l}\text { Solution for subcutaneous } \\
\text { administration }\end{array}$ \\
\hline M05BX & $\begin{array}{l}\text { Other medicines that } \\
\text { affect bone structure } \\
\text { and mineralization }\end{array}$ & Denosumab* & $\begin{array}{l}\text { Solution for subcutaneous } \\
\text { administration }\end{array}$ \\
\hline R03DX & $\begin{array}{l}\text { Other systemic drugs } \\
\text { for the treatment of } \\
\text { obstructive airways } \\
\text { diseases }\end{array}$ & Omalizumab* & $\begin{array}{l}\text { Lyophilizate for solution for } \\
\text { subcutaneous administration } \\
\text { solution for subcutaneous } \\
\text { administration }\end{array}$ \\
\hline S01LA & $\begin{array}{l}\text { Medicines preventing } \\
\text { vascular neoplasm }\end{array}$ & Ranibizumab & $\begin{array}{l}\text { Solution for intraocular } \\
\text { administration }\end{array}$ \\
\hline
\end{tabular}

Monoclonal antibodies are used to treat patients with high-cost nosologies. Rituximab is included in the list of medicines provided to patients with malignant neoplasms of lymphoid, hematopoietic, and related tissues. Natalizumab is included in the LIST of medicines for patients with multiple sclerosis.

For patients with the hemolytic-uremic syndrome, one of five additional high-cost nosologies, 
Eculizumab, is purchased for the $1^{\text {st }}$ time. For patients with juvenile arthritis with systemic onset, also an additional high-cost nosology, the monoclonal antibodies purchased are tocilizumab, adalimumab, and canakinumab.

The general pharmacopeia monograph "Filgrastims" includes the requirements for recombinant filgrastim (granulocyte-colony stimulating factor) obtained through the recombinant DNA technology using bacterial cells as an expression system.

Filgrastim preparations stimulate the proliferation and differentiation of neutrophils and release thereof from the bone marrow into the blood.

Filgrastim-based medicines are available in forms for parenteral use: injection (for intravenous and subcutaneous administration) and infusions.

It is important to note that the GPM "Filgrastims" does not apply to the modified filgrastims (pegylated filgrastims) (pegfilgrastim, lipegfilgrastim, and empegfilgrastim).

The list of vital and essential drugs for 2019 includes L03AA colony-stimulating factors (L03A Immunostimulants): Filgrastim (solution for intravenous and subcutaneous administration; solution for subcutaneous administration) and empegfilgrastim (solution for subcutaneous administration).

The general pharmacopeia monograph "Erythropoietin" includes the requirements for the erythropoietin (epoetins) obtained through the recombinant DNA technology using mammalian cells as an expression system.

Erythropoietin specifically stimulates the proliferation and differentiation of erythrocyte cells. Erythropoietin preparations are used for the prevention and treatment of anemia of various origins.

Recombinant erythropoietin-based drugs are available in the form for the parenteral use: Injection solution and lyophilizate. Lyophilizate can be supplied complete with a solvent approved for medical use.

It is important to note that the GPM "Erythropoietin" does not extend to the erythropoietin with a modified amino acid sequence (darbepoetin) and modified erythropoietin (pegylated erythropoietin).

In the list of vital and essential drugs for 2019, erythropoietin is included in the group B03X - Other antianemic drugs: Darbepoetin alpha, methoxypolyethylene glycol-epoetin beta, epoetin alpha, and epoetin beta.

The list of preferential provision drugs includes all four positions of erythropoietin in the indicated dosage forms, whereas darbepoetin alpha and methoxypolyethylene glycol-epoetin beta are prescribed by the decision of the medical committee.

The general pharmacopeia monograph "DNA Vaccines" defines that these are the drugs whose active substance is purified recombinant - plasmid/viral vectors obtained using recombinant DNA technology, containing one or more DNA sequences capable of inducing and/or activating an immune response to a pathogen or non-infectious disease. Typically, these plasmid/viral vectors contain DNA sequences necessary for selection and replication in bacterial or mammalian cells. In addition, they contain a eukaryotic promoter, an enhancer, and a sequence for termination/-polyadenylation of transcription to activate gene expression in vaccine recipients, and may also contain immunomodulating elements.

DNA vaccines can be bacterial cells with a plasmid or a single vector, which is usually a viral vector.

Biological pharmaceutical substances of these preparations are obtained using cultures of characterized cells, which may be bacteria, mammalian cells (in which case they are called a substrate), etc.

The requirements for a specific biological pharmaceutical substance and medicines based on them should be set out in the relevant pharmacopeial monographs or regulatory documents.

It is important to note that the GPM "DNA vaccines" do not apply to the vaccines based on live viral vector and to gene therapy drugs.

The examples of the DNA vaccines registered in Russia are: Hepatitis B recombinant vaccine, human papillomavirus quadrivalent recombinant vaccine, recombinant adsorbed human papillomavirus vaccine containing AS04 adjuvant, and bivalent.

The general pharmacopeia monograph "Genetically engineered human insulin preparations" applies to the genetically-engineered human insulin preparations obtained using recombinant DNA technology from genetically stable and safe microorganisms.

Genetic engineering drugs of human insulin are available in parenteral dosage forms.

It is important to note that the requirements of the GPM "Genetically engineered human insulin preparations" do not apply to bovine insulin, porcine insulin, and semi-synthetic insulin.

The list of vital and essential drugs for 2019 contains the following genetically engineered human insulin preparations for the treatment of diabetes mellitus:

- $\quad$ Short-acting insulins and their analogs for injection (A10AB): Insulin aspart, Insulin glulisine, insulin lispro, soluble insulin

Medium-duration action insulins and their analogs for injection (A10AB): (Human genetically engineered) insulin-isofan

Medium-duration or long-acting insulins and their analogs in combination with short-acting insulin for injection (A10AD): Two-phase insulin 
aspart, insulin degludec + insulin aspart, twophase insulin lispro, and insulin two-phase (human genetic engineering)

Long-acting insulins and their analogs for injection (A10AE): Insulin glargine, insulin degludec, and insulin detemir.

All the above insulin items are also included in the list of preferential provision drugs, whereas the insulin degludec + insulin aspart and insulin degludec are prescribed by the decision of the medical commission.

\section{Discussion}

As part of the work in 2019 to review the lists of medicines according to the results of the examination, the Commission of the Ministry of Health of Russia has proposed new BtM to be included in the list of vital and essential drugs for 2020, of which new monoclonal antibodies are the most significant ones for the treatment of a number of diseases, namely, mepolizumab, İxekizumab, dupilumab, ramucirumab, benralizumab, reslizumab, elotuzumab, sarilumab, and netakimab [11].

\section{Conclusion}

The subjects of BtM circulation in the Russian pharmaceutical market must take into account the requirements of the $14^{\text {th }}$ edition of the State Pharmacopeia at all circulation stages.

The regulatory documents for the registered medicines and their constituent pharmaceutical substances, as well as the pharmaceutical substances produced for sale and included in the state register of medicines for medical use, must be brought into line with the approved general pharmacopeia monographs and the monographs until January 1, 2022.

BtM occupies an important place in the list of vital and essential drugs and other restrictive lists.
It must be expected that new BtM, including monoclonal antibodies, would be reviewed and included in the relevant restrictive lists for 2020.

\section{References}

1. Zakharochkina ER. 8 rules for working with vaccines: A memo for pharmacy managers. Novaya Apteka. 2018;10:14-25.

2. Zakharochkina ER. Biological Medicines. United States: Annex to the Novaia Apteka Magazine; 2019.

3. Consultant Plus. Available from: http://www.consultant.ru. [Last accessed on 2020 Jun 15].

4. The "Pharma-2030" Strategy: Promoting Globalization. CIS GMP News Magazine, Autumn; 2018. Available from: https://www. gmpnews.net/magazine/gmpnews-eng-2-2-2018/\#page/28 [Last accessed on 2020 Jun 10].

5. Zakharochkina ER, Raisian MG, Behorashvili NY Interchangeability of medicinal products in the Eurasian economic union. Yerevan state medical university after $M$. Heratsi medicine. Sci Educ. 2017;23:106-10.

6. Zakharochkina ER, Garankina RY, Behorashvili NY, Lisovskaya SB, Bashilov AA, Petrushina NV. Analysis of measures to establish the institution of medications interchangeability. J Pharm Sci Res. 2018;10(10):2651-2.

7. Zakharochkina ER. Legal Field for the Formation of the Common Market of Medicinal Products of the Eurasian Economic Union. Moscow: Collection of Materials of the Days of Belarusian Science in Moscow: Scientific Achievements of the Republic of Belarus; 2017. p. 81-4

8. Zakharochkina ER, Maksimkina EA. Normative pool of documents on the formation of the common market of medicinal products of the Eurasian economic union. Bull Roszdravnadzor. 2017;5:63-70.

9. Zakharochkina ER, Raisian MG, Behorashvili NY, Garankina RY, Ryajemov VV, Simonyan M. Uniform rules for registering medicinal products in the Eurasian economic union. J Pharm Sci Res. 2018;10(5):1045-7.

10. Manerova OA, Markina AY. Early social orphanhood as a relevant problem of Russian health care (on the example of the Chelyabinsk region, Russia). Open Access Maced J Med Sci. 2019;7(11):1873-8. https://doi.org/10.3889/oamjms.2019.457

11. Protocol of the Meeting of the Commission of the Ministry of Health of the Russian Federation on the Formation of Lists of Drugs for Medical Use and the Minimum Range of Drugs Required for Medical Care; 2019. Available from: https://www.static-1. rosminzdrav.ru/system/attachments/attaches/000/046/251/ original $/ \% \mathrm{D} 0 \% 9 \mathrm{~F} \% \mathrm{D} 0 \% \mathrm{~A} 0 \% \mathrm{D} 0 \% 9 \mathrm{E} \% \mathrm{D} 0 \% \mathrm{~A} 2 \% \mathrm{D} 0 \% 9 \mathrm{E} \% \mathrm{D0}$ \%9A\%D0\%9E\%D0\%9B 18.07.2019.PDF?1563902866. https://doi.org/10.33941/age-info.com24(5)2018005. [Last accessed on 2020 Jun 10]. 